\title{
Determinan Perilaku Pengelolaan Keuangan pada UMKM di Kabupaten Kediri
}

\author{
Faradila Larasaty ${ }^{1}$ \\ Fakultas Ekonomi \\ Universitas Negeri Malang, Indonesia \\ Makaryanawati ${ }^{2}$ \\ Fakultas Ekonomi \\ Universitas Negeri Malang, Indonesia
}

\author{
Rizka Furqorina ${ }^{3}$ \\ Fakultas Ekonomi \\ Universitas Terbuka, Indonesia
}

\begin{abstract}
Surel : rizkafurqorina@ecampus.ut.ac.id
ABSTRAK

Penelitian ini bertujuan untuk mengetahui pengaruh pengetahuan keuangan, perencanaan keuangan dan pengendalian diri terhadap perilaku manajemen keuangan UMKM. Teknik pengambilan sampel dalam penelitian ini menggunakan metode convenience sampling. Data dikumpulkan menggunakan kuesioner. Penelitian ini menggunakan pendekatan kuantitatif dan metode analisis menggunakan regresi linier berganda. Hasil penelitian ini adalah financial knowledge dan financial planning memiliki efek positif pada perilaku manajemen keuangan UMKM. Self control tidak berpengaruh signifikan terhadap perilaku pengelolaan keuangan UMKM. Berdasarkan hasil penelitian, rata-rata responden memiliki pengetahuan keuangan yang baik dan telah melaksanakan perencanaan keuangan dengan baik sehingga ada perilaku manajemen keuangan yang baik.
\end{abstract}

Kata Kunci: Pengetahuan Keuangan; Perencanaan Keuangan; Pengendalian Diri; Manajemen Keuangan UMKM.

\section{Determinants of Financial Management Behavior in MSMEs in Kediri Regency}

\section{ABSTRACT}

This study aims to determine the effect of financial knowledge, financial planning and self-control on MSME's financial management behavior. The sampling technique in this study uses convenience sampling method. Data collected using questionnaire. This research used a quantitative approach and the analytical method used multiple linear regression. The results of this study are financial knowledge and financial planning have a positive effect on MSME's financial management behavior. Self control has no significant effect on the financial management behavior of SMEs. Based on the results of the study, the average respondent has good financial knowledge and has carried out financial planning well so there is good financial management behavior.

Keywords: Financial Knowledge; Financial Planning; Self Control; MSME`s Financial Management.

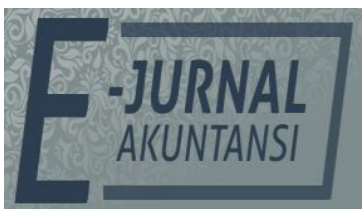

e-ISSN 2302-8556

Vol. 31 No. 10

Denpasar, Oktober 2021

Hal. 2467-2480

DOI:

10.24843/EJA.2021.v31.i10.p05

PENGUTIPAN:

Larasaty, F., Makaryanawati., \& Furqorina, R. (2021).

Determinan Perilaku

Pengelolaan Keuangan pada UMKM di Kabupaten Kediri.

E-Jurnal Akuntansi, 31(10), 2467-2480

RIWAYAT ARTIKEL:

Artikel Masuk:

3 Maret 2021

Artikel Diterima:

7 Oktober 2021

Artikel dapat diakses : https://ojs.unud.ac.id/index.php/Akuntansi/index 


\section{PENDAHULUAN}

Usaha Mikro Kecil dan Menengah (UMKM) merupakan salah satu faktor yang menjadi dasar pertumbuhan perekonomian Indonesia yang memberi kontribusi dalam menciptakan investasi nasional, produk domestik bruto nasional, penyerapan tenaga kerja dan menciptakan devisa nasional (Humaira, 2018). UMKM sebagai salah satu faktor pendukung pertumbuhan ekonomi di Indonesia, perkembangan UMKM memerlukan dukungan dan pengawasan dari berbagai pihak agar terhindar dari berbagai masalah. Salah satu permasalahan yang dihadapi oleh UMKM di Indonesia adalah pencatatan keuangan. Pencatatan keuangan yang tidak tersedia dengan baik dan tidak tepat dapat menimbulkan keputusan manajerial yang tidak tepat pula dan sering kali merugikan. Informasi akuntansi atau laporan keuangan yang memadai, sebagai wujud pengelolaan keuangan yang baik sangat dibutuhkan bagi pelaku UMKM sebagaimana telah diatur dalam SAK EMKM. Hal tersebut terjadi karena informasi akuntansi memberikan pengaruh yang dominan bagi kelangsungan atau keberhasilan sebuah usaha (Rini \& Laturette, 2016). Oleh sebab itu, perilaku pengelolaan keuangan yang efektif dan efisien perlu dilakukan oleh setiap UMKM untuk kelangsungan usahanya sehingga kontribusi UMKM terhadap pertumbuhan ekonomi dapat tercapai.

Perilaku keuangan adalah kemampuan seseorang dalam mengatur perencanaan, penganggaran, pemeriksaan, pengelolaan, pengendalian, pencairan dan penyimpanan dana keuangan sehari-hari (Kholilah \& Iramani, 2013). Perilaku keuangan yang sehat dapat ditunjukkan oleh adanya aktivitas perencanaan, pengelolaan dan pengendalian keuangan yang baik sehingga tercipta kesejahteraan keuangan. Perilaku keuangan berhubungan dengan tanggung jawab mengenai tata cara pengelolaan keuangan yang dilakukan oleh seseorang. Tanggung jawab dalam hal keuangan merupakan proses pengelolaan keuangan dan aset lain dengan cara yang produktif (Ida \& Dwinta, 2010). Pengelolaan keuangan merupakan upaya untuk memperoleh dana yang dibutuhkan, memanfaatkan atau mengalokasikan dana yang diperoleh, dan mendistribusikan hasil dari pemanfaatan dana dengan cara rasional yang tujuannya untuk menciptakan atau meningkatkan nilai (Sugeng, 2017). Pengelolaan keuangan penting untuk dilakukan setiap instansi atau perusahaan agar terhindar dari masalah keuangan. Adanya pengelolaan keuangan yang baik, seorang pelaku usaha akan lebih bijaksana dan bertanggungjawab dalam mengambil keputusan, sehingga kondisi keuangan perusahaan tetap dalam keadaan yang baik. Pengelolaan keuangan dapat dilihat dari beberapa hal, yaitu konsumsi, cash flow management, tabungan dan investasi serta manajemen utang (Dew \& Jing , 2011).

Teori Atribusi menjelaskan tentang perilaku seseorang mengungkapkan bahwa perilaku seseorang dapat dipengaruhi oleh beberapa faktor. Atribusi berguna untuk membantu memahami penyebab perilaku seseorang yang dapat berasal dari faktor internal dan eksternal. Atribusi dalam penelitian ini berguna untuk memahami penyebab perilaku seseorang dalam mengelola keuangannya. Teori Atribusi merupakan proses yang dilakukan untuk mencari jawaban mengenai penyebab perilaku yang dilakukan orang lain atau diri sendiri (Dayakisni \& Hudaniah, 2006). Penyebab internal cenderung mengarah pada sesuatu yang telah ada dari dalam diri seseorang seperti sifat, karakter seseorang 
dan kontrol. Penelitian ini menggunakan self control sebagai salah satu indikator yang diduga dapat mempengaruhi atau menjadi penyebab seseorang dalam mengelola keuangannya. Faktor eksternal dapat berasal dari lingkungan sekitar. Penelitian ini menggunakan financial knowledge dan financial planning sebagai faktor eksternal yang mempengaruhi perilaku pengelolaan keuangan seseorang.

Financial knowledge atau pengetahuan mengenai keuangan pada dasarnya dibutuhkan oleh individu khususnya setiap pelaku usaha dalam pengelolaan keuangan, sehingga dapat membuat keputusan keuangan secara efektif dengan menggunakan uang dengan bijak dan memberi manfaat pada ekonomi (Ida \& Dwinta, 2010). Keputusan keuangan yang dilaksanakan dalam kegiatan usaha secara efektif dapat membantu meningkatkan kinerja perusahaan. Peningkatan pengetahuan keuangan akan meningkatkan perilaku pengelolaan keuangan, karena pengetahuan keuangan memberikan pengaruh yang baik dalam pengambilan keputusan (Yulianti \& Silvy, 2013). Penelitian lainnya mengungkapkan semakin tinggi pengetahuan keuangan yang dimiliki seseorang, maka semakin bijak seseorang tersebut dalam mengelola keuangannya (Vincentius \& Linawati, 2014).

Faktor lain yang dapat mempengaruhi perilaku pengelolaan keuangan adalah perencanaan. Perencanaan penting dilakukan untuk kebutuhan financial agar terhindar dari kesulitan keuangan. Adanya perencanaan keuangan yang baik dapat memudahkan perusahaan untuk mencapai tujuan keuangannya. Perkiraan pemasukan dan pengeluaran penting untuk dilakukan setiap individu atau pelaku usaha agar memiliki kesiapan apabila terdapat pengeluaran yang terlalu banyak (Alexano, 2012). Penetapan tujuan jangka pendek maupun jangka panjang juga diperlukan dalam setiap perencanaan keuangan yang akan dibuat. Penelitian menyatakan seseorang yang melakukan perencanaan mengindikasikan bahwa terdapat kesiapan dalam dirinya untuk menghadapi kemungkinan-kemungkinan yang terjadi pada masa mendatang (Susanti \& Pardi, 2017).

Selain faktor eksternal yaitu pengetahuan keuangan dan perencanaan keuangan, terdapat faktor internal yang dapat mempengaruhi perilaku pengelolaan keuangan yaitu self control. Self control adalah keadaan seseorang yang dapat mengontrol dirinya dengan selalu mempertimbangkan faktor-faktor yang mempengaruhi setiap kejadian dan akibat yang ditimbulkan (Ida \& Dwinta, 2010). Self control dalam hal mengelola keuangan adalah aktivitas yang mendorong seseorang untuk menurunkan pembelian dalam rangka penghematan (Pritazahara \& Sriwidodo, 2015). Seseorang yang memiliki self control yang baik akan mampu mempertimbangkan setiap pengeluaran dengan tidak melakukan pemborosan dan mengoptimalkan pengeluaran untuk memenuhi kebutuhan yang tepat (Herlindawati, 2015). Oleh karena itu, adanya self control akan mendorong seseorang untuk melihat dan memperhatikan perbuatan yang akan dilakukan serta mempertimbangkan dampak akibat perbuatannya.

Penelitian terdahulu mengenai perilaku pengelolaan keuangan mengungkapkan bahwa literasi keuangan memiliki pengaruh langsung terhadap perilaku keuangan mahasiswa (Laily, 2013). Penelitian lain juga menyebutkan bahwa literasi keungan dan perencanaan keuangan berpengaruh positif dan signifikan terhadap perilaku pengelolaan keuangan pribadi yang terjadi pada pelaku usaha UMKM (Susanti \& Pardi, 2017). Penelitian lain menyebutkan 
pengetahuan keuangan, sikap keuangan dan kepribadian berpengaruh positif terhadap perilaku manajemen keuangan pada pelaku UMKM di Kabupaten Bantul (Humaira, 2018). Namun hasil berbeda ditunjukkan pada penelitian yang dilakukan oleh (Herdjiono \& Damanik, 2016), hasil dari penelitian tersebut menunjukkan bahwa pengetahuan keuangan tidak berpengaruh terhadap manajemen keuangan pribadi pada mahasiswa. Perbedaan hasil tersebut karena setiap individu memiliki kondisi keuangan serta perilaku yang berbeda. Selain itu, perbedaan terjadi karena perbedaan responden yang digunakan.

Dalam penelitian ini, responden yang digunakan adalah pelaku UMKM skala menengah di Kabupaten Kediri. Pemilihan pelaku UMKM skala menengah sebagai responden penelitian ini karena pengelolaan keuangan pada UMKM telah memiliki pedoman atau standar dalam menyusun laporan keuangan sebagai bentuk pengelolaan keuangannya. UMKM skala menengah juga merupakan usaha yang memiliki penghasilan bruto lebih besar dibanding skala mikro dan kecil. Selain itu, pengelolaan keuangan pelaku usaha UMKM skala menengah diharapkan lebih baik dari pelaku usaha UMKM skala mikro dan kecil. Hal ini karena, pelaku usaha UMKM skala menengah lebih memiliki struktur organisasi yang jelas dan pengelolaan manajerial yang lebih teratur, serta pengetahuan dan pengelolaan yang lebih baik. Sehingga pengelolaan keuangan yang dilakukan oleh pelaku UMKM diharapkan lebih terstruktur, efektif dan efisien dibandingkan dengan pengelolaan keuangan pribadi yang dilakukan oleh mahasiswa yang tidak memiliki standar tertentu yang telah ditetapkan. Standar yang diatur untuk pelaku UMKM tersebut adalah SAK ETAP dan kemudian disederhanakan menjadi SAK EMKM.

Financial knowledge dapat dimiliki setiap orang dengan mengembangkan financial skill dan financial tools. Financial skill adalah sebuah teknik untuk membuat keputusan dalam pengelolaan keuangan pribadi (Ida \& Dwinta, 2010). Financial tools merupakan alat dan sarana yang digunakan dalam pembuatan keputusan pengelolaan keuangan. Hilgert \& Hogarth, (2003) menyatakan bahwa konsumen yang memiliki financial knowledge cenderung memiliki tanggung jawab dalam pengelolaan keuangan. Guru yang memiliki pengetahuan tentang keuangan lebih memiliki manajemen keuangan yang baik dalam hal menabung. (Zaimah, et al., 2013) Selanjutnya, individu yang memiliki financial knowledge dan sikap pengelolaan keuangan yang baik akan berpikir untuk melakukan pengelolaan secara bijak dalam merencanakan investasi keluarga untuk masa depan (Yulianti \& Silvy, 2013). Financial knowledge yang diperoleh dari pendidikan atau kursus keuangan pribadi berpengaruh pada sikap dan perilaku (Johan, et al., 2021) .

Teori Atribusi menyebutkan bahwa faktor-faktor yang dapat mempengaruhi perilaku seseorang adalah faktor eksternal dan internal. Faktor eksternal pada Atribusi yang dapat mempengaruhi perilaku seseorang dalam mengelola keuangan salah satunya adalah financial knowledge. Financial knowledge dapat berasal dari pendidikan, seminar, pelatihan, lingkungan, kegiatan yang dilaksanakan dan pengalaman pribadi. Faktor-faktor eksternal tersebut dapat mendorong seseorang untuk memperoleh pengetahuan mengenai keuangan yang lebih memadai sehingga pengelolaan keuangan yang dilakukan dapat berjalan dengan baik. Sebagai contoh, seseorang yang kurang memiliki financial knowledge akan semakin terhambat untuk pengambilan keputusan yang tepat dalam 
pengelolaan keuangan perusahaannya. Sedangkan seseorang yang memiliki financial knowledge yang baik akan memiliki pandangan yang lebih kuat dalam pengambilan keputusan dengan bijak dan bertanggungjawab. Hal ini terjadi karena hasil pembelajaran yang memadai di masa lalu. Oleh karena itu hipotesis pertama dalam penelitian ini adalah sebagai berikut.

$\mathrm{H}_{1}$ : Financial knowledge berpengaruh terhadap perilaku pengelolaan keuangan pada UMKM.

Selain pengetahuan keuangan, faktor yang dapat mempengaruhi perilaku pengelolaan keuangan adalah perencanaan keuangan atau financial planning. Perencanaan keuangan penting untuk mengontrol keuangan baik pada perusahaan maupun individu. Seseorang atau perusahaan melakukan sebuah perencanaan keuangan untuk menyusun pengeluaran yang diperlukan bagi kelangsungan hidup perusahaan yang dijalaninya. Pencatatan semua pemasukan dan pengeluaran merupakan cara yang bijak untuk mengetahui kondisi keuangan (Alexano, 2012). Penelitian yang dilakukan oleh Johan, et al., (2021), responden mengikuti pendidikan kursus keuangan pribadi selama 14 minggu, diajarkan untuk melakukan financial planning dan hasilnya responden mempunyai peilaku pengelolaan keuangan yang lebih matang. Adanya perencanaan dapat membuat kehidupan perusahaan dapat terlaksana dengan baik dan tepat. Pembuatan perkiraan pemasukan dan pengeluaran penting untuk dilakukan sebuah perusahaan agar memiliki kesiapan apabila terdapat pengeluaran dalam jumlah besar yang terjadi secara tiba-tiba. Bagi perusahaan yang penghasilannya terbatas, perencanaan perlu dilakukan untuk menghindari masalah keuangan yang akan dihadapi.

Berkaitan dengan Teori Atribusi, financial planning merupakan salah satu faktor eksternal yang dapat mempengaruhi perilaku pengelolaan keuangan seseorang. Apabila sebuah perusahaan melakukan perencanaan untuk setiap pengeluarannya maka tempat usaha tersebut memiliki pengelolaan keuangan yang baik. Hal ini karena perencanaan yang dilakukannya dapat membantu dalam mengendalikan atau mengelola keuangan yang dimiliki sehingga dapat terhindar dari masalah keuangan. Sebaliknya, perusahaan yang tidak melakukan perencanaan pada setiap pengeluarannya akan berhadapan dengan masalah keuangan karena tidak mengelola keuangannya dengan baik dan bertanggungjawab. Berdasarkan penjelasan tersebut, maka hipotesis kedua pada penelitian ini adalah sebagai berikut.

$\mathrm{H}_{2}$ : Financial planning berpengaruh terhadap perilaku pengelolaan keuangan pada UMKM.

Teori Atribusi juga menyebutkan bahwa faktor yang dapat mempengaruhi perilaku seseorang adalah faktor internal. Faktor internal adalah faktor psikologis yang berasal dari dalam diri seseorang. Self control adalah keadaan seseorang yang dapat mengontrol dirinya dengan selalu mempertimbangkan faktor-faktor yang mempengaruhi setiap kejadian dan akibat yang ditimbulkan (Ida \& Dwinta, 2010). Self control yang dimiliki setiap orang akan berbeda-beda sesuai dengan kemampuan yang dimiliki untuk mengendalikan diri sendiri. Seseorang yang memiliki self control yang baik akan dapat mengendalikan dirinya dengan baik dalam berbagai situasi yang dihadapi. 
Kontrol diri berpengaruh signifikan positif terhadap pengelolaan keuangan (Herlindawati, 2015). Sejalan dengan penelitian (Sampoerna \& Haryono, 2021), perilaku pengelolaan keuangan dipengaruhi oleh gaya hidup hedonistik dan self control. Hal ini mengindikasikan bahwa semakin tinggi kontrol terhadap diri yang dimiliki maka akan semakin baik pengelolaan keuangan yang dilakukannya. Self control dapat membantu seseorang terhindar dari permasalahan keuangan apabila seseorang tersebut mampu mengontrol dirinya dalam menggunakan uang yang dimiliki. Sebagai contoh, individu yang memiliki self control yang buruk akan kesulitan dalam mengontrol pemenuhan kebutuhan dan keinginannya, sehingga individu tersebut dapat mengalami kesulitan dalam keuangannya. Hal ini dapat terjadi karena jumlah pengeluaran tidak seimbang dengan besarnya pemasukan yang diterima. Hal tersebut juga dapat terjadi pada perusahaan yang sedang dijalankan oleh orang tersebut. Sedangkan seseorang yang memiliki self control yang baik dapat mengendalikan keinginannya dan memenuhi kebutuhannya maupun kebutuhan perusahaan yang dijalankannya dengan bijak dan bertanggungjawab sehingga terhindar dari permasalahan keuangan. Berdasarkan penjelasan, maka hipotesis ketiga pada penelitian ini adalah sebagai berikut.

$\mathrm{H}_{3}$ : Self control berpengaruh terhadap perilaku pengelolaan keuangan pada UMKM.

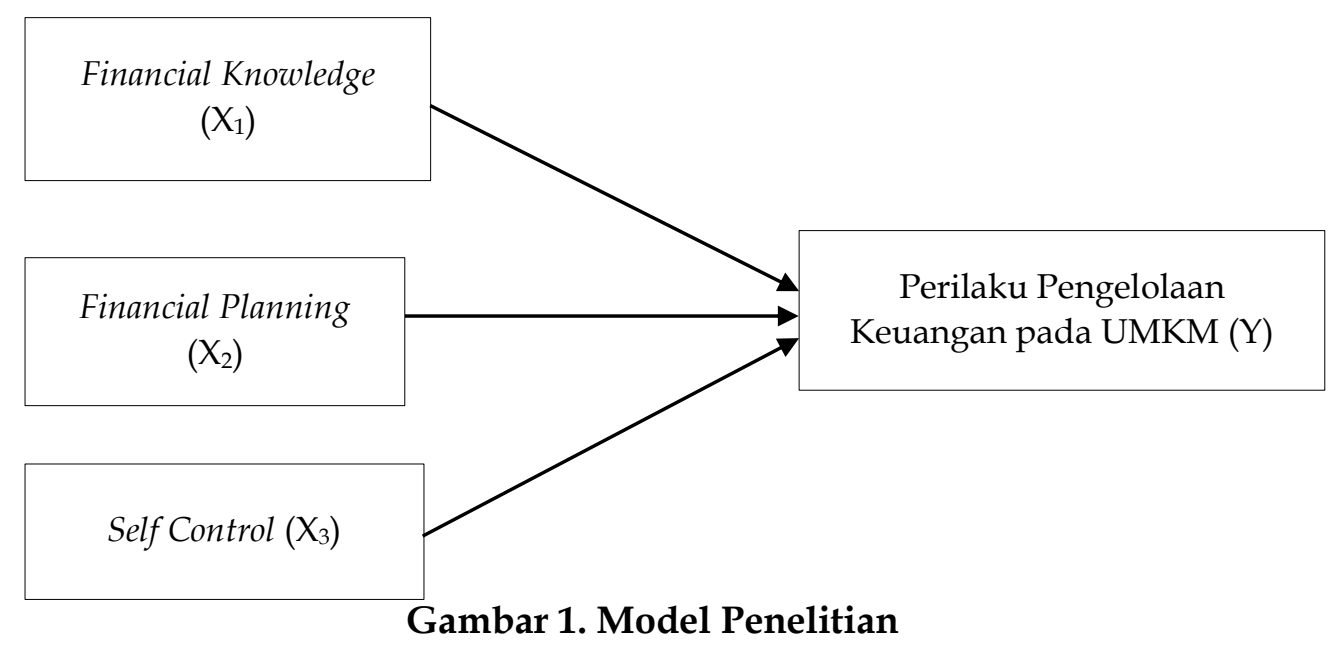

Sumber: Data Penelitian, 2019

Gambar 1, merupakan model yang digunakan pada penelitian ini. Variabel dependen pada penelitian ini adalah perilaku pengelolaan keuangan pada UMKM, sedangkan variabel independen pada penelitian ini adalah financial knowledge, financial planning, dan self control. Variabel independen pada penelitian ini dikembangkan dari Teori Atribusi.

\section{METODE PENELITIAN}

Populasi dalam penelitian ini adalah UMKM skala menengah yang terdaftar di Kabupaten Kediri. UMKM skala menengah tersebut adalah yang memenuhi kriteria menurut (Undang-undang Nomor 20 Tahun 2008 Tentang Usaha Mikro, Kecil dan Menengah), yaitu memiliki kekayaan bersih lebih dari Rp. 500.000.000 Rp. 10.000.000.000 dan memiliki hasil penjualan tahunan lebih dari Rp. 2.500.000.000 - Rp. 50.000.000.000. Jumlah populasi sebanyak 129 UMKM yang 
terdaftar pada Dinas Koperasi dan UMKM Kabupaten Kediri dan tersebar di 26 Kecamatan. Teknik pengambilan sampel dalam penelitian ini menggunakan metode convenience sampling. Sampel penelitian adalah UMKM skala menengah pada 26 Kecamatan yang terdaftar di Kabupaten Kediri.

Penelitian ini menggunakan data primer untuk memperoleh data berupa jawaban atau informasi dari responden. Dalam memperoleh data primer yang dibutuhkan, penelitian ini menggunakan kuesioner atau angket yang disebarkan pada UMKM skala menengah yang terdaftar di Kabupaten Kediri.

Instrumen penelitian yang digunakan dalam pengumpulan data pada penelitian ini adalah kuesioner. Sebagai instrumen penelitian, kuesioner yang telah ditetapkan akan disebarkan pada subjek penelitian. Variabel financial knowledge, financial planning, self control dan perilaku pengelolaan keuangan pada penelitian ini diukur menggunakan skala likert dengan membuat alternatif jawaban. Alternatif jawaban atas pernyataan yang telah dibuat akan diberi dari yang tertinggi yaitu 5 sampai skor yang terendah yaitu 1 . Makna dari angka pada masing-masing pilihan jawaban yaitu, 1 = sangat tidak setuju, 2 = tidak setuju, $3=$ netral, $4=$ setuju, 5 = sangat setuju. Sesuai dengan identifikasi setiap variabel yang akan dikaji serta model yang disusun dalam tinjauan literatur, maka ditetapkan kisi-kisi atau indikator yang akan diukur sehingga menjadi item pernyataan. Jumlah pernyataan yang telah dibuat adalah sebanyak 25 butir pernyataan.

Penelitian ini menggunakan analisis regresi linear berganda untuk uji hipotesis. Analisis Regresi Linear Berganda digunakan untuk melihat hubungan fungsional antara variabel dependen dan variabel independen dengan jumlah variabel independen lebih dari satu (Nazir, 2014). Analisis regresi linear berganda dilakukan untuk meneliti hubungan sebab akibat antara variabel dependen dengan variabel independen. Penelitian ini meneliti seberapa besar pengaruh variabel independen yaitu financial knowledge, financial planning dan self control terhadap perilaku pengelolaan keuangan UMKM (variabel dependen). Rumus persamaan yang digunakan adalah sebagai berikut.

Keterangan:

$$
Y=\alpha+\beta_{1} X_{1}+\beta_{2} X_{2}+\beta_{3} X_{3}+\varepsilon
$$

$$
\begin{array}{ll}
\mathrm{Y} & : \text { Perilaku pengelolaan keuangan UMKM } \\
\mathrm{a} & : \text { Konstanta } \\
\mathrm{X}_{1} & \text { : Financial knowledge } \\
\mathrm{X}_{2} & : \text { Financial planning } \\
\mathrm{X}_{3} & : \text { Self control } \\
\beta_{1}, \beta_{2}, \beta_{3} & : \text { koefisien regresi untuk masing-masing variabel independent } \\
\varepsilon & : \text { Error }
\end{array}
$$

\section{HASIL DAN PEMBAHASAN}

Tabel 1, menunjukkan terdapat responden yang berada pada usia kurang dari 25 tahun, yaitu berjumlah 7 orang atau 8 persen, 39 orang pada usia 25-30 tahun atau sekitar 46 persen, 33 orang pada 31-40 tahun atau 38 persen, 5 orang pada usia 4150 tahun atau sekitar 6 persen dan 2 orang atau 2 persen responden pada usia 50 tahun keatas. Tabel 2 menunjukkan responden yang berasal dari SMA/SMK sebanyak 17 orang atau 20 persen, diploma sebanyak 28 orang atau 32 persen dan S1 sebanyak 41 orang atau 48 persen. Selain itu, Tabel 3 yang menunjukkan lama 
usaha yang telah dijalankan, terdapat 3 UMKM yang memiliki usaha kurang dari 1 tahun atau sebesar 3 persen, 26 UMKM atau 30 persen menjalankan usahanya selama 1-5 tahun, 29 UMKM atau 34 persen telah menjalankan usahanya selama 6-10 dan 28 UMKM atau 33 persen telah menjalankan usahanya selama lebih dari 10 tahun.

\section{Tabel 1. Karakteristik responden}

\begin{tabular}{ccc}
\hline Keterangan & Jumlah & Persentase (\%) \\
\hline$<25$ & Usia (Tahun) & 8 \\
$25-20$ & 7 & 46 \\
$31-40$ & 39 & 38 \\
$41-50$ & 33 & 6 \\
$>50$ & 5 & 2 \\
& 2 & \\
SMA/SMK & Tingkat Pendidikan & 20 \\
Diploma & 17 & 32 \\
S1 & 28 & 48 \\
& 41 & 3 \\
$<1$ & Lama Usaha (Tahun) & 30 \\
$1-5$ & 3 & 34 \\
$6-10$ & 26 & 33 \\
$>10$ & 29 & 28 \\
\hline
\end{tabular}

Sumber: Data Penelitian, 2019

Tabel 4, menunjukkan bahwa financial knowledge, financial planning, self control dan perilaku pengelolaan keuangan yang dimiliki rata-rata responden tergolong baik. Rata-rata responden memilih jawaban pada skala 4 dan 5 yang artinya rata-rata responden memiliki jawaban yang tinggi pada setiap item pernyataan dengan jawaban setuju dan sangat setuju.

Tabel 4. Statistik Deskriptif

\begin{tabular}{lccccc}
\hline Variabel & N & Minimum & Maksimum & Mean & $\begin{array}{l}\text { Std. } \\
\text { Deviation }\end{array}$ \\
\hline Financial Knowledge & 86 & 21 & 35 & 29,37 & 2,744 \\
Financial Planning & 86 & 18 & 30 & 24,81 & 2,716 \\
Self Control Pengelolaan & 86 & 17 & 29 & 23,01 & 2,716 \\
Perilaku Pra & 19 & 30 & 25,01 & 2,403
\end{tabular}

Sumber: Data Penelitian, 2019

Berdasarkan hasil regresi pada tabel hasil uji regresi linear berganda dapat diperoleh hasil uji parsial $\mathrm{t}$ pada masing-masing variabel independen terhadap variabel dependen. Pada variabel financial knowledge $\left(X_{1}\right)$ diperoleh nilai signifikansi sebesar $0,036<0,05$. Hal tersebut dapat diartikan bahwa variabel financial knowledge $\left(\mathrm{X}_{1}\right)$ berpengaruh signifikan terhadap perilaku pengelolaan keuangan UMKM. Maka, hipotesis yang menyatakan financial knowledge berpengaruh terhadap perilaku pengelolaan keuangan pada UMKM $\left(\mathrm{H}_{1}\right)$ diterima. Pada variabel financial planning $\left(\mathrm{X}_{2}\right)$ diketahui nilai signifikansi sebesar $0,016<0,05$. Hal ini berarti variabel financial planning $\left(X_{2}\right)$ berpengaruh signifikan terhadap perilaku pengelolaan keuangan UMKM. Maka hipotesis yang menyatakan financial planning berpengaruh terhadap perilaku pengelolaan keuangan pada UMKM $\left(\mathrm{H}_{2}\right)$ diterima. 
Sedangkan untuk variabel self control $\left(X_{3}\right)$ diketahui nilai signifikansi sebesar $0,809>0,05$. Hal ini berarti variabel self control $\left(X_{3}\right)$ tidak berpengaruh signifikan terhadap perilaku pengelolaan keuangan UMKM. Maka hipotesis yang menyatakan self control berpengaruh terhadap perilaku pengelolaan keuangan pada UMKM $\left(\mathrm{H}_{3}\right)$ ditolak.

Tabel 5. Hasil Uji Regresi Linear Berganda

\begin{tabular}{cccccc}
\hline Variabel & $\begin{array}{c}\text { Unstandardized } \\
\text { Coefficients }\end{array}$ & \multicolumn{4}{c}{$\begin{array}{c}\text { Standardizied } \\
\text { Coefficients }\end{array}$} \\
\cline { 2 - 4 } & $B$ & Std. Error & Beta & T & Sig. \\
\hline (Constant) & 11,601 & 2,772 & & 4,185 & 0,000 \\
$X_{1}$ & 0,221 & 0,103 & 0,252 & 2,133 & 0,036 \\
$X_{2}$ & 0,257 & 0,104 & 0,291 & 2,470 & 0,016 \\
$X_{3}$ & 0,024 & 0,098 & 0,027 & 0,242 & 0,809 \\
\hline
\end{tabular}

Sumber: Data Penelitian, 2019 berikut.

Berdasarkan Tabel 5, dapat diperoleh model persamaan regresi sebagai

$$
\mathrm{Y}=11,601+0,221 \mathrm{X} 1+0,257 \mathrm{X} 2+0,024 \mathrm{X} 3+\varepsilon
$$

Hasil pengujian koefisien determinasi pada penelitian ini menunjukkan bahwa pengaruh variabel independen terhadap variabel dependen masih terbatas. Keterangan mengenai koefisien determinasi pada penelitian ini dapat dilihat lebih lanjut pada Tabel 6, berikut.

\section{Tabel 6. Hasil Koefisien Determinasi}

\begin{tabular}{ccccc}
\hline $\mathrm{R}$ & $\mathrm{R}$ Square & Sig. & Adjusted R Square & Std. Error of the Estimate \\
\hline 0,489 & 0,239 & 0,000 & 0,211 & 2,134 \\
\hline
\end{tabular}

Sumber: Data Penelitian, 2019

Nilai $\mathrm{R}^{2}$ sebesar 0,239 artinya pengaruh variabel independen, yaitu financial knowledge $\left(X_{1}\right)$, financial planning $\left(X_{2}\right)$ dan self control $\left(X_{3}\right)$ terhadap variabel dependen, yaitu perilaku pengelolaan keuangan UMKM (Y) adalah sebesar 23,9 persen. Nilai $\mathrm{R}^{2}$ sebesar 0,239 atau 23,9 persen tergolong kecil, sehingga mengindikasikan bahwa pengaruh variabel independen terhadap variabel dependen terbatas atau lemah.

Hasil dari pengujian hipotesis pertama menunjukkan bahwa financial knowledge berpengaruh positif signifikan terhadap perilaku pengelolaan keuangan UMKM. Hal ini berarti bahwa semakin baik pengetahuan keuangan yang dimiliki seseorang, maka dapat menciptakan perilaku pengelolaan keuangan yang baik pula pada UMKM. Faktor yang dapat meningkatkan pengetahuan keuangan seseorang salah satunya adalah pendidikan. Semakin tinggi seseorang menempuh pendidikan, maka semakin bertambah pengetahuan keuangan yang dimiliki (Amanah \& Iradianty, 2016). Pendidikan dapat dimiliki seseorang dengan berbagai cara, baik pendidikan formal melalui sekolah, perkuliahan, seminar dan sebagainya, maupun pendidikan informal melalui pengalaman atau kegiatan yang dilakukan. Responden penelitian memiliki pendidikan yang baik terbukti dari jenjang pendidikan yang ditempuh dan juga pengalaman yang dimiliki.

Seseorang yang memiliki pendidikan yang lebih tinggi akan lebih waspada terhadap kelangsungan hidupnya maupun perusahaan yang dikelolanya. Oleh karena itu seseorang yang memiliki pendidikan tinggi lebih memperhatikan kondisi keuangannya dengan mengelola keuangannya secara baik agar UMKM 
yang mereka kelola terhindar dari masalah keuangan. Seseorang yang memiliki pengetahuan keuangan akan memperhatikan pendapatan dan pengeluaran yang dimiliki perusahaan, selain itu, seseorang yang memiliki pengetahuan keuangan juga akan memperhatikan kemampuan perusahaan dalam berhutang sehingga dapat meminimalkan risiko terjadinya masalah keuangan. Selain itu, orang-orang yang memiliki pengetahuan keuangan juga mengetahui bagaimana memperlakukan uang yang dikelolanya dengan baik melalui investasi aset yang dimiliki. Hal ini didukung oleh penelitian Amanah \& Iradianty, (2016)yang menyebutkan bahwa orang-orang yang berpendidikan akan memilih berbagai tools keuangan yang memudahkan untuk melakukan transaksi atau investasi dan akan mencari tahu cara-cara untuk menyimpan aset. Selain itu, dengan mengetahui cara-cara untuk menyimpan aset yang dimiliki, seseorang yang memiliki pengetahuan keuangan yang baik juga akan memerhatikan jenis jaminan dan jangka waktu pelunasan ketika hendak meminjam dana pada lembaga keuangan.

Berdasarkan jawaban responden atas kuesioner yang dibagikan, rata-rata responden memiliki pendidikan terakhir pada jenjang strata satu atau S1, selain itu responden juga telah mengelola UMKM selama lebih dari 6 tahun. Hal ini menjadi pendukung bahwa terdapat financial knowledge yang memadai melalui jenjang pendidikan terakhir yang ditempuh serta lama usaha yang dijalankan sehingga tercipta pengelolaan keuangan UMKM yang baik. Selain itu, para pengelola keuangan pada UMKM juga berada pada rata-rata usia yang produktif, yaitu 25-50 tahun. Sehingga, pada usia yang produktif tersebut seseorang akan berusaha mengembangkan usaha yang dilakukannya dengan baik melalui pengelolaan keuangan yang baik.

Hasil dari pengujian hipotesis kedua menunjukkan bahwa financial planning berpengaruh positif terhadap perilaku pengelolaan keuangan UMKM. Hal ini berarti bahwa semakin baik perencanaan keuangan yang dilakukan perusahaan, maka semakin baik pula perilaku pengelolaan keuangan yang dilakukan oleh UMKM. Perencanaan keuangan atau financial planning sangat penting untuk dilakukan oleh para pengusaha khususnya pelaku UMKM, karena dengan adanya perencanaan keuangan para pelaku usaha dapat menentukan tujuan keuangan yang akan dicapai dalam jangka waktu tertentu. Selain itu, dengan adanya perencanaan yang diikuti dengan tujuan keuangan, para pelaku UMKM dapat membuat keputusan keuangan dengan bijak sesuai dengan tujuan keuangan yang telah ditetapkan, sehingga tujuan keuangan tersebut dapat tercapai. Keputusan keuangan yang dilakukan dengan baik dan benar dapat membuat UMKM terhindar dari berbagai macam kesalahan dalam pengambilan keputusan baik jangka panjang maupun jangka pendek untuk keberlangsungan hidup UMKM tersebut. Dengan dilakukannya financial planning dalam kegiatan UMKM dapat membantu para pelaku UMKM untuk mengelola keuangannya dengan baik. Financial Planning dapat diperoleh dengan hasil yang maksimal dengan memperhatikan tujuan keuangan yang dibuat, memahami akibat dari setiap keputusan keuangan dan mengevaluasi kondisi keuangan secara berkala (Sundjaja, 2010).

Rata-rata responden memilih jawaban setuju pada setiap pernyataan dalam variabel financial planning, yaitu mengenai pemahaman kondisi keuangan 
perusahaan, pembuatan sasaran keuangan, membuat tujuan keuangan, membuat alternatif tujuan keuangan, melakukan evaluasi dan bertidak sesuai tujuan keuangan. Hal ini mengindikasikan bahwa responden telah melakukan perencanaan keuangan dengan cukup baik. Financial planning yang dilakukan oleh UMKM juga didukung dengan faktor usia yang dimiliki oleh para pelaku usaha atau pengelola UMKM. Responden dalam penelitian ini berada pada usia yang produktif, yaitu pada rentang usia 25-50 tahun. Usia produktif yang dimiliki seseorang akan mendorong seseorang tersebut melakukan berbagai hal untuk kelangsungan hidup usahanya, salah satunya adalah dengan menerapkan financial planning. Selain itu, para pengelaku UMKM atau pengelola UMKM yang menjadi responden, rata-rata telah mengelola UMKM lebih dari 6 tahun. Hal ini dapat menjadi pendukung terdapat financial planning yang baik dan memadai dalam mengelola keuangan UMKM melalui lama usaha yang dijalankan serta usia produktif yang dimiliki pengelola.

Hasil dari pengujian hipotesis ketiga menunjukkan bahwa self control tidak berpengaruh terhadap perilaku pengelolaan keuangan UMKM. Hal ini berarti perilaku pengelolaan keuangan UMKM yang baik atau buruk tidak disebabkan oleh baik atau buruknya self control yang dimiliki oleh pelaku UMKM. Hasil penelitian ini sesuai dengan penelitian (Ida \& Dwinta, 2010) yang menyebutkan bahwa self control tidak berpengaruh terhadap pengelolaan keuangan. Hasil penelitian ini tidak sesuai dengan hasil penelitian yang dilakukan Amanah \& Iradianty, (2016) dan Herlindawati, (2015) yang menyebutkan bahwa self control berpengaruh terhadap perilaku pengelolaan keuangan serta tidak sesuai dengan hipotesis ketiga. Hal tersebut terjadi karena kontrol diri yang dimiliki pelaku UMKM, tidak mempengaruhi perilakunya dalam mengelola keuangan yang dikerjakannya. Self control yang dimiliki seseorang akan berbeda satu sama lainnya. Berdasarkan jenis kelamin, self control yang dimiliki laki-laki lebih baik dibandingkan perempuan, terutama dalam hal belanja. Laki-laki akan berbelanja berdasarkan manfaatnya sedangkan perempuan akan berbelanja hanya karena kesenagan semata (Kusumowidagdo, 2010). Lebih lanjut, laki-laki akan bertindak lebih rasional, sedangkan perempuan lebih didasarkan pada faktor-faktor kesenangan dalam melakukan sebuah keputusan pembelian (Astari, Widagda, \& A., 2014). Namun, perempuan cenderung lebih memiliki kemauan untuk melaporkan penggunaan keuangan yang baik dibandingkan laki-laki (Putri \& Rahyuda, 2017).

Pada penelitian ini, responden yang mendominasi adalah perempuan, sehingga self control yang dimiliki kurang maksimal hanya berada pada persentase yang tergolong cukup baik, tetapi perempuan akan melakukan pengelolaan keuangan yang baik dibandingkan laki-laki. Oleh karena itu, self control pada penelitian ini tidak berpengaruh terhadap perilaku pengelolaan keuangan UMKM. Hal ini karena, responden yang mendominasi adalah perempuan, dimana seperti yang dijelaskan sebelumnya bahwa apabila dibandingkan dengan lakilaki, perempuan lebih memiliki keinginan untuk melaporkan keuangannya dengan baik. Tetapi, perempuan cenderung memiliki self control yang kurang baik dibanding laki-laki. 


\section{SIMPULAN}

Berdasarkan hasil analisis dan pembahasan yang telah dilakukan dapat diketahui bahwa financial knowledge berpengaruh terhadap perilaku pengelolaan keuangan UMKM. Hal tersebut karena para pelaku UMKM memiliki pengetahuan yang tinggi, yang dapat dilihat dari jenjang pendidikan terakhir yang ditempuh. Seseorang yang memiliki pendidikan yang lebih tinggi akan lebih waspada terhadap kelangsungan hidupnya maupun perusahaan yang dikelolanya. Financial planning juga berpengaruh terhadap perilaku pengelolaan keuangan UMKM. Hal tersebut karena financial planning sangat penting untuk dilakukan oleh para pengusaha khususnya pelaku UMKM, karena dengan adanya perencanaan keuangan mereka dapat menentukan tujuan keuangan yang akan dicapai dalam jangka waktu tertentu. Sehingga, dengan adanya tujuan keuangan dalam financial planning dapat menciptakan perilaku pengelolaan keuangan yang baik. Self control tidak berpengaruh terhadap perilaku pengelolaan keuangan UMKM. Self control yang dimiliki pelaku UMKM tidak menghambat pengelolaan keuangan yang dilakukan. Baik atau buruknya perilaku pengelolaan keuangan UMKM tidak disebabkan oleh baik atau buruknya self control yang dimiliki oleh pengelola atau pelaku UMKM, melainkan dipengaruhi oleh faktor-faktor selain self control.

Penelitian ini memiliki beberapa keterbatasan, yaitu hanya menggunakan kuesioner sebagai instrumen pengumpulan data yang akan mempengaruhi hasil penelitian, sehingga tidak mempertimbangkan jawaban lain atau pendapat responden terhadap topik penelitian. Saran untuk penelitian selanjutnya sebaiknya tidak hanya menggunakan kuesioner dalam metode pengumpulan data. Sehingga data yang diperoleh peneliti tidak hanya berdasarkan jawaban dari responden atas pernyataan yang telah disusun oleh peneliti. Misalnya dengan menambah metode wawancara atau observasi langsung kepada responden yang dapat menjelaskan secara langsung keadaan yang sebenarnya terjadi di lapangan. Penelitian selanjutnya sebaiknya lebih banyak menggunakan responden yang memiliki tingkat pendidikan terakhir minimal S1 serta mengelola UMKM pada usia produktif dan lebih dari 6 tahun, sehingga memiliki financial knowledge dan financial planning yang lebih baik. Penelitian selanjutnya dapat menggunakan responden laki-laki dan perempuan yang jumlahnya seimbang, karena laki-laki bertindak lebih rasional dalam pembelian dibanding perempuan, sedangkan perempuan cenderung memiliki keinginan untuk melaporkan penggunaan keuangan dengan baik dibanding laki-laki. Bagi pelaku UMKM dapat mengadakan pelatihan atau seminar terkait pengetahuan keuangan dan perencanaan keuangan agar perilaku pengelolaan keuangan pada UMKM dapat terlaksana dengan baik

\section{REFERENSI}

Alexano, P. (2012). Manajemen Keuangan untuk Pemula dan Orang Awam. Jakarta Timur: Laskar Aksara.

Amanah, E., D. R, \& A. Iradianty. (2016). Pengaruh Financial Knowledge, Financial Ettitude dan External Locus of Control Terhadap Personal Financial Management Behavior pada Mahasiswa S1 Universitas Telkom. Eproceeding of Management, 3, hal. 1228. 
Dew, J., \& Jing , X. J. (2011). The Financial Management Behavior Scale: Development and Validation. Journal of Financial Conseling and Planning, 22(12), 43-59.

Ghozali, I. (2018). Aplikasi Analisis Multivariate dengan Program IBM SPSS 25 (9 ed.). Semarang: Universitas Diponegoro Semarang.

Dayakisni, T., \& Hudaniah. (2006). Psikologi Sosial. Malang: Universitas Muhammadiyah Malang.

Heider, F. (1958). The Psychology of Interpersonal Relations. New York: WIley.

Herlindawati, D. (2015). Pengaruh Kontrol Diri, Jenis Kelamin, dan Pendapatan Terhadap Pengelolaan Keuangan Pribadi Mahasiswa Pascasarjana Universitas Negeri Surabaya. Jurnal Ekonomi Pendidikan dan Kewirausahan, $3(2)$.

Hilgert, A., \& Hogarth, J. M. (2003). Household Financial Management: The Connection Between Knowledge and Behavior. Federal Reserve Bulletin, 89(7), 309-322.

Humaira. (2018). Pengaruh Pengetahuan Keuangan, Sikap Keuangan dan Kepribadian Terhadap Perilaku Manajemen Keuangan pada Pelaku UMKM Sentra Kerajinan Batik Kabupaten Bantul. Jurnal Nominal Barometer Riset Akuntansi dan Manajemen Indonesia, 7(1).

Astari, W., Widagda, K., \& A., I. G. (2014). Pengaruh Perbedaan Jenis Kelamin dan Kontrol Diri Terhadap Keputusan Pembelian Implusif Produk Parfum. Jurnal Manajemen Universitas Udayana, 3(3), 546-560.

Kholilah, N., \& Iramani, R. (2013). Studi Financial Management Behavior pada Masyarakat Surabaya. Journal of Business and Banking, 3(1), 69-80. doi:http://dx.doi.org/10.14414/jbb.v3i1.255

Ida, \& Dwinta, C. Y. (2010). Pengaruh Locus of Control, Financial Knowledge, Income Terhadap Financial Management Behavior. Jurnal Bisnis dan Akuntansi, 12(3), 131-144. doi:https:// doi.org/10.34208/jba.v12i3.202

Herdjiono, I., \& Damanik, L. A. (2016). Pengaruh Financial Attitude, Financial Knowledge, Parental Income Terhadap Financial Manajemen Behavior. Jurnal Manajemen Teori dan Terapan, 9(3). doi:http://dx.doi.org/10.20473/jmtt.v9i3.3077

Johan, I., Rowlingson, K., \& Appleyard, L. (2021). The Effect of Personal Finance Education on The Financial Knowledge, Attitudes and Behaviour of University Students in Indonesia. Journal of Family and Economic Issues, 42, 351-367.

Kusumowidagdo, A. (2010). Pengaruh Desain Atmosfir Toko Terhadap Perilaku Belanja: Studi Kasus Pengaruh Gender Terhadap Respon Pengunjung Toko. International Research Jurnal of Business Studies, 3(1), 17-32.

Laily, N. (2013). Pengaruh Literasi Keuangan Terhadap Perilaku Mahasiswa dalam Mengelola Keuangan. . Jurnal Pendidikan Akuntansi, 1(4), 277-285. doi:http://dx.doi.org/10.26675/jabe.v1i4.6042

Nazir. (2014). Metode Penelitian. Bogor: Ghalia Indonesia.

Pritazahara, R., \& Sriwidodo, U. (2015). Pengaruh Pengetahuan Keuangan dan Pengalaman Keuangan Terhadap Perilaku Perencanaan Investasi dengan Self Control sebagai Variabel Moderating. Jurnal Ekonomi dan Kewirausahaan, 15(1), 28-37. 
Putri, D. R., \& Rahyuda, H. (2017). Pengaruh Tingkat Financial Literacy dan Faktor Sosiodemografi Terhadap Perilaku Keputusan Investasi Individu. E-jurnal Ekonomi dan Bisnis Universitas Udayana, 6(9), 3407-3424.

Rini, D. A., \& Laturette, K. (2016). Relevansi Sikap Berakuntansi Pelaku UMKM Muda dan Penggunaan Informasi Akuntansi Terhadap Keberhasilan Usaha. Jurnal Akuntansi Aktual, 3(3), 199-206.

Robbins, S. P., \& Judge, T. A. (2008). Perilaku Organisasi (12 ed.). Jakarta: Salemba Empat.

Sampoerna, A. E., \& Haryono, N. A. (2021). Pengaruh Financial Literacy, Income, Hedonism Lifestyle, Self-Control, dan Risk Tolerance terhadap Financial Management Behavior pada Generasi Milenial Kota Surabaya. Jurnal Ilmu Manajemen, 9(3).

Sugeng, B. (2017). Manajemen Keuangan Fundamental. Jogjakarta: Deepublish.

Sundjaja, A. M. (2010). Perencanaan Keuangan untuk Mencapai Tujuan Financial. Comtech: Computer, Mathematics and engineering Applications, 1(1), 183-191.

Susanti, A., Ismunawan, \& Pardi, E. A. (2017). Tingkat Pendidikan, Literasi Keuangan dan Perencanaan Keuangan Terhadap Perilaku Keuangan UMKM di Surakarta. Telaah Bisnis, 45-46.

Undang-undang Nomor 20 Tahun 2008 Tentang Usaha Mikro, Kecil dan Menengah. (t.thn.).

Vincentius, A., \& Linawati, N. (2014). Hubungan Faktor Demografi dan Pengetahuan Keuangan dan Perilaku Keuangan Karyawan Swasta di Surabaya. Jurnal Finesta, 2(2), 35-39.

Yulianti, N., \& Silvy, M. (2013). Sikap Pengelolaan Keuangan dan Perilaku Perencanaan Investasi Keluarga di Surabaya. Journal of Business and Banking, 3(1), 57-68.

Zaimah, R., Sarmila, M., Lyndon, N., \& Azima. (2013). Financial Behaviors of Female Teachers in Malaysia. Asian Social Science, 9(8). doi:10.5539/ass.v9n8p34 